\title{
Kształtowanie przestrzeni miejskiej jako mikrokosmos polityki publicznej. Przypadek Warszawy
}

„Moim zdaniem najważniejsza linia podziału przebiega między ludźmi, którzy troszczą się tylko o własny ogródek, a tymi, którzy interesują się tym, co jest za płotem".

Vaclav Havel, prezydent Czech ${ }^{1}$

\section{Streszczenie}

Przedmiotem artykułu są niektóre związki i analogie między polityką kształtowania przestrzeni miejskiej a polityką publiczną w szerokim rozumieniu, zarówno w wymiarze miasta (tu na przykładzie Warszawy), jak i generalnym, ogólnopaństwowym. Zasadne wydaje się twierdzenie, że stan przestrzeni publicznej w sensie fizycznym w bardzo dużym stopniu zależy od dominującej koncepcji oraz kondycji polityki publicznej prowadzonej na różnych szczeblach. Ale i vice versa, tzn. ta ostatnia jest często produktem lub w jakimś sensie odzwierciedleniem utrwalonych wzorów traktowania miejsc powszechnie dostępnych i uczęszczanych, np. w środowisku miejskim.

Słowa kluczowe: polityka publiczna, polityka miejska, ład przestrzenny, urbanistyka

\section{The shaping of urban space as a microcosm of public policy. The case for Warsaw}

\section{Abstract}

The subject of the article are some of the relationships and analogies between urban space shaping and public policy making in the broad sense, both on the city (here Warsaw as

\footnotetext{
1 Wywiad z V. Havlem, „Gazeta Wyborcza”, 21-22.11.1998.
} 
a case study) and general, nationwide scale. It seems reasonable to claim that the state of public space in the physical sense to a large extent depends on the dominating concept and the performance of public policy pursued at different levels. But, vice versa, as well, i.e. the latter is often the product or in some sense reflects the established patterns of attitudes towards public places available and generally attended to, e.g. in an urban environment. Keywords: public policy, urban policy, spatial order, urban planning

Politykę kształtowania przestrzeni miejskiej oraz politykę publiczną w szerokim rozumieniu łączy wiele współzależności, a także analogii. W szczególności trudno byłoby nie zgodzić się z tezą, że pomyślny rozwój fizycznej przestrzeni publicznej wymaga istnienia stosownej sfery polityki publicznej, czyli m.in. bliskiej współpracy organów administracji z organizacjami mieszkańców oraz inwestorami rynkowymi w zakresie zagospodarowania przestrzennego i urbanistyki. W sensie zaś bardziej ogólnym - miasto, jako wspólnota i dobro wspólne, wymaga dobrego współdziałania, dialogu i kompromisu korzystnego dla wszystkich, a nie tylko dla najsilniejszych czy najbardziej wpływowych mieszkańców, przedsiębiorców i instytucji, w tym działających w nich urzędników i polityków.

\section{Dwa rozumienia przestrzeni: fizyczne i symboliczne}

Zacznijmy jednak od objaśnień i uściśleń terminologicznych. Słowo „przestrzeñ” występuje w powszechnym obiegu w co najmniej dwóch znaczeniach. W węższym - czysto fizycznym, dosłownym oraz w szerszym - symbolicznym, bardziej abstrakcyjnym, poniekąd metaforycznym. Innymi słowy, rozróżnienie to wskazuje, że przestrzeń to nie tylko fizyczne otoczenie, ale i fenomen społeczny, kulturowy i polityczny. Na przykład przestrzeń miejska to nie tylko budynki, ale i to, co się dzieje między budynkami, między mieszkającymi lub przebywającymi tam ludźmi². To habitat, czyli całe środowisko człowieka, miejsce zamieszkania, pracy, edukacji, spędzania wolnego czasu, fizycznego przemieszczania się i kontaktów międzyludzkich, uczestnictwa w życiu publicznym, kulturalnym i towarzyskim.

Na ład przestrzenny w sensie ścisłym składają się takie elementy, jak: krajobraz, sieć osiedleńcza i układ zabudowań w jej mniejszych fragmentach, architektura, estetyka. Polityka przestrzenna jest najczęściej definiowana jako działalność władzy

2 Szerzej zob. B. Jałowiecki, M.S. Szczepański, Miasto i przestrzeń w perspektywie socjologicznej, Wydawnictwo Naukowe Scholar, Warszawa 2002. 
publicznej określająca zasady i kierunki zagospodarowania przez człowieka jego otoczenia. Jednym z jej instrumentów jest planowanie przestrzenne. Szczególnym obszarem odpowiedzialności władzy jest kształtowanie przestrzeni publicznej oraz jej relacji z przestrzenią prywatną, osobistą, na którą składają się m.in. nieruchomości czy posesje należące do indywidualnych osób bądź rodzin.

$\mathrm{W}$ wypadku miast przestrzeń publiczna to ten fragment przestrzeni miejskiej, który służy bezpośrednim kontaktom społecznym i zaspokajaniu innych potrzeb zbiorowych, a zarazem jest fizycznie dostępny dla wszystkich zainteresowanych jednostek ${ }^{3}$. To ta strefa, w której znajdują się otwarte dla wszystkich miejsca i obiekty użyteczności publicznej o nie prywatnym, choć różnorakim, statusie własnościowym (państwowym, komunalnym, spółdzielczym). Są powszechnie dostępne, chociaż przebywanie w nich jest czasem ograniczane - odpłatnością (np. zakupem biletu na basen miejski) bądź wymogami bezpieczeństwa (np. restrykcjami dotyczącymi ruchu kołowego, wstępu do określonych sektorów na stadionach lub placach miejskich podczas imprez masowych).

W każdej zamieszkałej fizycznej sieci przestrzennej - i to jest drugi aspekt omawianego pojęcia i zagadnienia - powstają jednak także jakieś relacje interpersonalne, które kreują swoistą przestrzeń społeczną. Zachodzą tam na przykład interakcje międzykulturowe i transakcje wymienne, powstają stosunki własnościowe i układ władzy. Toczy się tam życie zbiorowe, zawiązuje się lub nie określona umowa społeczna. Ale istnieją tam również enklawy prywatności. W opozycji do przestrzeni prywatnej, osobistej, która w tym ogólniejszym wypadku odnosi się do życia indywidualnego, rodzinnego, relacji zachodzących w wąskich grupach koleżeńskich czy sąsiedzkich, mówimy w tym kontekście o istnieniu przestrzeni (sferze, domenie) publicznej jako bardziej generalnym, abstrakcyjnym zjawisku społecznym i kulturowym. Na gruncie nauki bywa ona różnie definiowana. Na przykład dla J. Osińskiego sfera publiczna oznacza obszar działań i współpracy podmiotów prawa publicznego, instytucji gospodarczych, środowisk lokalnych, obywateli, rodzin itp. ${ }^{4}$. Według G. Rydlewskiego, można ją rozumieć jako „przestrzeń, w której dochodzi do artykulacji i agregacji interesów politycznych, walki o uzyskanie i utrzymanie wpływu na władzę publiczną oraz jako środowisko, w którym odbywa się progra-

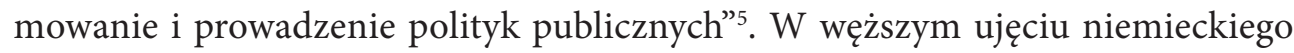

3 Zob. P. Lorens, Definiowanie przestrzeni publicznej, w: Problemy ksztattowania przestrzeni publicznej, red. P. Lorens, J. Martyniuk-Pęczek, Wydawnictwo Urbanista, Gdańsk 2012, s. 10.

4 J. Osiński, Sfera publiczna i sfera prywatna, w: Polityka publiczna we współczesnym świecie, red. J. Osiński, Oficyna Wydawnicza SGH, Warszawa 2014, s. 31-33.

5 G. Rydlewski, Polska polityczna 2012/2013. Sfera publiczna jako środowisko decydowania politycznego, Dom Wydawniczy Elipsa, Warszawa 2014, s. 9. 
filozofa J. Habermasa jest to obszar dyskursu politycznego i wymiany poglądów na tematy publiczne w społeczeństwie ${ }^{6}$.

Ład społeczny czy publiczny pod wieloma względami przypomina fizycznie pojmowany ład przestrzenny. Występujące podobieństwo niektórych elementów tożsamości obu ładów skłania do stosowania w tym kontekście całej gamy obrazowych i poręcznych w wielu sytuacjach - także w ramach refleksji naukowej - metafor. Między tymi dwoma porządkami występują nie tylko pewne znaczące zbieżności i analogie, ale i wzajemne oddziaływania. Przykładowo, odpowiednikiem prywatnego zawłaszczania fizycznej przestrzeni publicznej jest prywatyzacja szerzej rozumianej domeny publicznej, np. przez wpływowe podmioty gospodarcze, maksymalizujące przede wszystkim zysk prywatny i dobro osobiste, a nie dobro wspólne. To ostatnie bywa zwykle chronione przez sferę publiczną, która - jak się najczęściej podkreśla - winna być otwarta, powszechnie dostępna i transparentna.

Formowanie szerszej przestrzeni publicznej polega na układaniu się ludzi ze sobą i rozwiązywaniu wspólnych problemów, a więc na prowadzeniu - w takim czy innym zakresie i formie - polityki publicznej. Jej integralnym elementem jest polityka kształtowania publicznej przestrzeni - także w sensie fizycznym - w skali regionów, miast i gmin. Działania w każdym z tych lokalnych wymiarów można potraktować jako szczególny przypadek (a nierzadko jednocześnie też lustro, odbicie) polityki kształtowania przestrzeni publicznej w skali całego państwa.

Widać to szczególnie na przykładzie takich dużych miast jak Warszawa. Ich funkcjonowanie można bez wątpienia uznać za jedną z form życia publicznego lub jako sposób organizowania w danej przestrzeni usług publicznych ${ }^{7}$. Jakość przestrzeni publicznej w obu wyróżnionych wcześniej znaczeniach w poważnym stopniu określa jakość codziennego życia człowieka i szerszych zbiorowości, w tym poziom zadowolenia i satysfakcji życiowej mieszkańców miast. Miasto bezpieczne, zasobne, wygodne, ekologiczne, ładne i przyjazne mieszkańcom to sukces miejskiej polityki publicznej, to w istocie najważniejszy miernik i sprawdzian jej słuszności i efektywności.

\section{Polityka miejska jako polityka publiczna}

Polityka miejska może być postrzegana jako swoisty mikrokosmos ogólnokrajowej polityki publicznej, jako laboratorium zarządzania sferą publiczną w szerszej,

6 J. Habermas, Strukturalne przeobrażenia sfery publicznej, Wydawnictwo Naukowe PWN, Warszawa 2007.

7 Zob. M. Castells, Kwestia miejska, PWN, Warszawa 1982; A. Merrifield, Nowa kwestia miejska, Wydawnictwo Naukowe PWN, Warszawa 2016. 
ogólnopaństwowej skali. W obu wymiarach pojawiają się bowiem te same bądź podobne pytania. Przykładowo:

- jak sprawnie i harmonijnie urządzać, organizować wspólną przestrzeń, także reformować, modernizować ją - odgórnie czy też oddolnie, autorytarnie czy demokratycznie?

- jaką rolę w tych procesach powinny odgrywać instytucje publiczne oraz podmioty należące do dwóch pozostałych sektorów - rynkowego i obywatelskiego?

- czym jest społeczeństwo (lokalna wspólnota mieszkańców) jako system uprawnień i zobowiązań?

- czym jest interes publiczny? Na ile może on być utożsamiany z interesem instytucji publicznych, np. spółek państwowych (w rodzaju PKP) czy komunalnych, agencji administrujących publicznym majątkiem?

- jak daleko władza w procesach rządzenia może posuwać się w swoim interwencjonizmie? Czy powinna w ogóle forsować projekty wpisujące się w logikę i doktrynę tzw. inżynierii społecznej?

Na obu płaszczyznach - ogólnopaństwowej i miejskiej - występują podobne mechanizmy i tendencje, które można obserwować tak w skali makro, jak i - niczym w soczewce $-\mathrm{w}$ skali mikro.

Wśród kwestii polityczno-prawnych i ustrojowych znajdują się takie wspólne zagadnienia, jak np. zakres kompetencji organów władzy, rola trzech wspomnianych wyżej sektorów - państwowego, rynkowego i obywatelskiego - w rządzeniu oraz relacje między nimi. Polityka miejska jest bardziej demokratyczna (partycypacyjna), gdy przewiduje rozwinięty system konsultacji z mieszkańcami (vide instytucje demokracji lokalnej jak budżet partycypacyjny czy poprzedzające większe inwestycje miejskie konsultacje społeczne). Z drugiej strony - jest mniej obywatelska, gdy wyklucza takie mechanizmy lub np. sprzyja powstawaniu grodzonych osiedli, dzielących i odseparowujących od siebie ludzi. Styl rządzenia i polityka lokalnych włodarzy mogą być policentryczne, w wypadku kiedy wspierają decentralizację, lub monocentryczne, gdy zakłada się, że miasto może mieć tylko jedno centrum, a system zarządzania nim powinien być układem ściśle hierarchicznym.

Wiele podobieństw i analogii daje się także zauważyć, jeśli chodzi o podejmowane w polityce publicznej na różnych poziomach sprawy gospodarcze i społeczne, rozstrzygane w polityce budżetowej, inwestycyjnej, reprywatyzacyjnej, socjalnej. Chodzi m.in. o uregulowania w zakresie transportu publicznego czy usług społecznych, ich komercjalizacji, urynkowienia itp. W tej dziedzinie za swoisty odpowiednik czy namiastkę np. polityki transportowej państwa mogą być uważane działania dotyczące komunikacji miejskiej, w tym realizowana w wielu miastach „polityka rowerowa”. Polityka miejska może być uznana za zekonomizowaną i prorynkową, gdy ułatwia 
prywatyzację, komercjalizację substancji miejskiej, co w skrajnych wypadkach oznacza całkowite utożsamianie miasta z jednym wielkim przedsiębiorstwem. $\mathrm{Z}$ drugiej strony, może być w mniejszym lub większym stopniu prospołeczna, gdy jej celami są przede wszystkim zrównoważone zaspokajanie różnych potrzeb, komfort i jakość życia ogółu mieszkańców, ich bezpieczeństwo, ich uczestnictwo w życiu kulturalnym, kontakty międzyludzkie.

Władze lokalne mogą promować wizję miasta otwartego, integrującego i egalitarnego, bez barier i dla wszystkich członków społeczności: starych i młodych, zdrowych, chorych i niepełnosprawnych, pieszych, rowerzystów i zmotoryzowanych, smakoszy różnych rodzajów kuchni, w tym wegetarian itp. Ale też, z drugiej strony, ratusz może sprzyjać kształtowaniu miasta zamkniętego, wykluczającego i elitarno-ekskluzywnego, które ogranicza różnorodność i pluralizm, zaniedbuje potrzeby mniejszości, nie dba o osoby marginalizowane, nie bierze pod uwage preferencji i gustów wyznawców różnych stylów życia, w ogóle bądź w niewystarczającym stopniu stara się godzić rozmaite, często sprzeczne, interesy grupowe.

Odpowiednikiem krajowej polityki proekologicznej są nie tylko lokalne zabiegi przeciwdziałające zanieczyszczeniom powietrza (np. smogowi) lub okolicznych wód, do których odprowadzane są miejskie ścieki, ale i tzw. zielona urbanistyka (przewidująca dużo zieleni w metropoliach, czym generalnie wyróżniają się np. projekty i praktyka skandynawska) oraz tzw. zielona architektura, której przykładem mogą być budynki z ogrodami na dachach (w rodzaju nowego gmachu uniwersyteckiej biblioteki na warszawskim Powiślu). Z podejściem prospołecznym i proekologicznym łączą się elementy polityki prozdrowotnej, choćby takie jak: promowanie zajęć sportowo-rekreacyjnych, umożliwianie bezpłatnego korzystania ze sprzętu do fitness czy minisiłowni „pod chmurką", ułatwianie dojazdu do pracy na rowerze dzięki rozbudowanej sieci ścieżek rowerowych i systemom wypożyczania jednośladów, jak np. stołeczny Veturilo itp.

Jeszcze innym przykładem analogii między działaniami podejmowanymi na szczeblu rządowym i samorządowym może być modna i zyskująca ostatnio na popularności w Polsce polityka historyczna, prowadzona także przez władze lokalne w odniesieniu do muzeów, pomników, miejsc pamięci, nazewnictwa ulic, rond i placów, patronów szkól, tablic i symboli umieszczanych w przestrzeni miejskiej.

Współcześnie na całym świecie rośnie znaczenie polityki miejskiej. Staje się ona w coraz większym stopniu przedmiotem zainteresowania nie tylko geografów czy ekonomistów (od dość dawna drążących temat urbanizacji), ale i politologów, którzy np. analizują, jak J. Pierre, różne typy rządzenia na tym poziomie zorganizowania społecznego (model menedżerski, korporatystyczny, prowzrostowy i socjalny) ${ }^{8}$.

\footnotetext{
8 J. Pierre, The Politics of Urban Governance, Palgrave Macmillan, Houndmills 2011.
} 
Zwiększają się rola i znaczenie tzw. nowych ruchów miejskich, które w opozycji do działań często niekompetentnej i aroganckiej władzy samorządowej oraz agresywnych aktorów rynkowych próbują formułować alternatywne, obywatelskie wizje rozwoju aglomeracji. Kształtowany przez te oddolne ruchy nowoczesny „miastopogląd” podkreśla wartość przestrzeni miejskiej jako dobra wspólnego ${ }^{9}$. Coraz bardziej docenia się tę problematykę w Unii Europejskiej, czego symbolicznym wyrazem było uzupełnienie przed paru laty nazwy Dyrekcji Generalnej Komisji Europejskiej zajmującej się polityką regionalną o pojęcie urban policy. W Polsce po raz pierwszy opracowano strategiczny dokument rządowy pt. Krajowa Polityka Miejska, przyjęty formalnie przez Radę Ministrów w październiku $2015 \mathrm{r}$.

Amerykański filozof polityki B. Barber przeciwstawia ostatnio wyższą jakość i wiarygodność polityki miast - nie najlepszej, wręcz kiepskiej, współczesnej kondycji polityki państw ${ }^{10}$. Deklaruje się jako gorący orędownik światowego rządu miast, a nie państw. Twierdzi - generalnie nie bez podstaw i trafnie, choć zapewne ze sporą dozą przesady - że państwa narodowe i ich polityka poniosły porażkę, gdyż stały się ideologiczne, zatraciły się w jałowych i całkowicie abstrakcyjnych sporach i debatach o wielkich ideach, jak: rynek kontra państwo, socjalizm przeciwko konserwatyzmowi, neoliberalizm kontra państwo opiekuńcze itp. Tymczasem na poziomie miast, a więc - jak byśmy powiedzieli, uściślając to rozumowanie i terminologię - w lokalnej polityce publicznej, wciąż najważniejsze pozostaje rozwiązywanie, w sposób pragmatyczny, bardzo konkretnych problemów społecznych, takich jak np. prowadzenie szkół i szpitali, zagwarantowanie sprawności policji i straży pożarnej, dostawa prądu, wody i gazu, odbiór śmieci, tworzenie miejsc pracy, radzenie sobie z imigrantami. We wszystkich tych sferach miasta działają, a państwa okazują się nieskuteczne - oznajmia, uogólniając (przy tym niewątpliwie idealizując te pierwsze i postponując te drugie) B. Barber. Przy okazji eksponuje on znaczenie demokratycznych ram i standardów w procesach rządzenia. „Publiczna przestrzeń to po prostu synonim demokracji” - przypomina. Dlatego wszelkie ograniczanie dostępu do obywatelskiej przestrzeni powinno być zakazane. „Miasto to wolność”, twierdzi, a jego „ulice zawsze muszą być dostępne dla wszystkich" - podkreśla ${ }^{11}$.

9 Szerzej zob. H. Lefebvre, Prawo do miasta, „Praktyka Teoretyczna” 2012, nr 5; D. Harvey, Bunt miast. Prawo do miasta i miejska rewolucja, Fundacja Bęc Zmiana, Warszawa 2012; K. Nawratek, Dziury w całym. Wstęp do miejskich rewolucji, Wydawnictwo Krytyki Politycznej, Warszawa 2012; M. Cesarski, Fikcje rynku mieszkaniowego a prawo do miasta, w: Współczesny matrix? Fikcja w życiu gospodarczym, politycznym i społecznym, red. J. Osiński, Oficyna Wydawnicza SGH, Warszawa 2015.

${ }_{10}$ B. Barber, Gdyby burmistrzowie rzadzili światem, Warszawskie Wydawnictwo Literackie Muza SA, Warszawa 2014.

11 Wywiad z B. Barberem, „Gazeta Wyborcza”, 3.10.2014. 
Nie jest to jednak pogląd powszechny, podzielany przez wszystkich. W podejściu do przestrzeni miejskiej sensu stricto zarysowują się i ujawniają różnego rodzaju koncepcje. Przystając na pewne uogólnienie, w sensie modelowym można by wśród nich wyróżnić co najmniej dwie skrajne opcje, odwołujące się do dwóch odmiennych generalnych doktryn ekonomiczno-społeczno-politycznych.

Pierwszą z nich jest leseferyzm przestrzenny, podejście hiperliberalne, które opiera się na takich podstawowych założeniach, jak: prymat indywidualizmu, apoteoza prywatnej własności, lekceważenie bądź negowanie walorów wspólnoty, wiara $\mathrm{w}$ sensowność oddania wszystkiego w pacht wolnemu rynkowi i drapieżnej konkurencji. Przekonanie, że wspólne oznacza niczyje, a co najmniej jest drugo- czy trzeciorzędne, że nie wolno pod żadnym pozorem krępować swobody gospodarczej prowadzi do wniosku, że np. tereny miejskie warto rozsprzedać prywatnym inwestorom i deweloperom, by sami decydowali o tym, co z nimi zrobić, aby przynosiły zyski - skoro ziemia, która nie zarabia, po prostu marnuje się itd. W zgodzie z tą optyką i sposobem myślenia urbaniści i architekci stają się rzecznikami inwestorów, zarządzanie przestrzenią zamienia się w żywioł, każdy „bierze swoje sprawy we własne ręce", a pożądany stan rzeczy zaczyna przypominać dziki kapitalizm neoliberalny w modelowym wyobrażeniu M. Thatcher.

Drugie, opozycyjne względem poprzedniego podejście to interwencjonizm przestrzenny, który zakłada, że warto i trzeba porządkować oraz kształtować wspólną przestrzeń jako dobro publiczne, dbać o jej spójność i jakość. Zagospodarowanie tej przestrzeni nie powinno polegać na eksploatacji tego zasobu niczym surowca. Takie podejście jest uzasadnione i konieczne, gdyż leseferyzm i wieczna improwizacja w tej dziedzinie - w myśl omawianego stanowiska - bywają wielce ryzykowne i mogą zbyt drogo kosztować, np. rujnować środowisko naturalne i więzi społeczne, prowadzić do rozwoju miasta pod dyktando deweloperów, producentów samochodów czy firm reklamowych. Towarzyszy temu przekonanie, że tzw. niewidzialna ręka rynku często jest także ślepa, m.in. na piękno czy estetykę miejsc publicznych. Dlatego trzeba cierpliwie negocjować i uzgadniać interesy różnych podmiotów i grup mieszkańców, uwzględniać rozmaite potrzeby, zaś w ostatniej instancji - uznawać prymat wspólnoty i racji ogólnospołecznych nad partykularną, jawną i ostentacyjną prywatą. Warto też w związku z tym inteligentnie i długofalowo planować, koordynować różne przedsięwzięcia i projekty, strategicznie myśleć o rozwoju miasta. 


\section{Jak kształtować przestrzeń miejską? Wskazania urbanistów}

Urbanistyka jako sztuka kształtowania przestrzeni miejskiej, planowania i budowania miasta ma wiele zbieżności z polityką publiczną, co najmniej zaś ma wyraźne odniesienia do jednego z jej ważnych aspektów, jakim jest formowanie fizycznej przestrzeni publicznej. Jedną z często przypominanych na gruncie urbanistyki zasad jest ta, która mówi, że w dobrze zaprojektowanym mieście przestrzeń publiczna powinna zajmować około jednej trzeciej jego powierzchni. Wśród tzw. rynkowców, zwolenników bardziej ekonomicznego podejścia do gospodarki przestrzennej, nie brakuje jednak orędowników poglądu, że takie „rozluźnianie” miasta byłoby nadmierną rozrzutnością, zaś gęściejsza zabudowa ma wiele walorów, m.in. ma być „bardziej miejska” i przytulna.

Nowoczesna urbanistyka - podobnie zresztą jak zręby nowoczesnej polityki publicznej, w tym społecznej - narodziła się w końcu XIX w., gdy żywiołowy, napędzany industrializacją rozrost zachodnich miast wymknął się spod kontroli, stwarzając wiele zagrożeń społecznych: sanitarnych, zdrowotnych, demograficznych, kryminalnych, komunikacyjnych, przyrodniczych, w końcu estetycznych. Zaczęto zastanawiać się, dokąd odprowadzać ścieki, gdzie budować fabryki, by dym z kominów nie zatruwał dzielnic mieszkalnych, którędy poprowadzić drogi i trakcję kolejową, jakie tereny pozostawić wolne od zabudowy.

Na przełomie stuleci często porównywano miasto do żywego organizmu, używając takich medycznych terminów jak "tkanka miejska” i niszczące ją „nowotwory”, „zielone płuca miasta”, „chirurgia urbanistyczna”, „krążenie”, „komunikacyjny krwiobieg" itp. Był to przejaw modnych wówczas pozytywistyczno-organicystycznych wizji społeczeństwa, w których również miasto traktowane było jak organizm złożony z różnych komórek - w założeniu harmonijnie ze sobą współpracujących, ale też czasem niebezpiecznych dla zdrowia i życia, grożących śmiertelnym rakiem, gdy jedne z nich nadmiernie namnażają się kosztem innych ${ }^{12}$. Wymienione metafory stosowano pewnie także dlatego, że we wspomniane działania terapeutyczne i profilaktyczne względem przestrzeni miejskich aktywnie angażowało się wielu lekarzy, ówczesnych Judymów.

Zrodzona w okresie międzywojennym XX w. doktryna modernizmu, niezależnie od związanego z nią stylu architektonicznego, miała także swój wymiar urbanistyczny. Rysowała wizję nowej przestrzeni dla „nowego człowieka”. W myśl jej założeń miasto

12 Zob. G. Piątek, Miejskie pryszcze i nowotwory, „Gazeta Wyborcza”, 16.05.2014. 
miało stać się miejscem dużo lepszym do życia, miało symbolizować i odzwierciedlać bardziej demokratyczne i egalitarne społeczeństwo. Budynki mieszkalne miały być nowoczesne, czyste $\mathrm{w}$ formie, pełne światła i osadzone w terenach zielonych. Dużą rolę w sformułowaniu i propagowaniu tej filozofii - w wielu punktach utopijnej, jak się rychło okazało, i co następnie wytykało wielu krytyków - odegrał słynny szwajcarsko-francuski architekt i urbanista Le Corbusier (1887-1965), zwany „papieżem” modernizmu. Opracowana przy jego walnym udziale i ogłoszona w 1933 r. wpływowa Karta Ateńska zawierała wiele idei Corbusierowskich, takich jak: potrzeba rozdzielenia w miastach stref mieszkalnych od przemysłowych, ruchu kołowego od pieszego (aby zapewnić większe bezpieczeństwo), wprowadzanie dużo zieleni i terenów rekreacyjnych pod samym domem, uwzględnianie infrastruktury społecznej w zabudowie, kreowanie miejsc wspólnych. Karta głosiła: „Interes publiczny powinien zawsze stać przed interesem prywatnym".

Ogromną wartość otwartej i egalitarnej przestrzeni miejskiej podkreśla współcześnie m.in. J. Gehl, duński architekt i urbanista, jeden z największych obecnie na świecie autorytetów w dziedzinie urbanistyki. „Publiczny składnik naszego życia zanika - mówi - dlatego ważne jest to, żeby miasta zapraszały ludzi do wspólnej przestrzeni”"13. Istotne z tego punktu widzenia są dla niego zmiany w zakresie preferowanych środków transportu i sposobów przemieszczania się w mieście. „Kiedy ograniczamy ruch samochodów, życie w miastach od razu staje się bogatsze. Nie ma spalin, hałasu, ludzie wychodzą na ulice, przybywa kawiarni, można swobodnie rozmawiać, słychać muzykę" - przekonuje J. Gehl' ${ }^{14}$.

Dobrą ilustracją tej prawidłowości są dla niego przemiany, jakie nastąpiły pod tym względem w Kopenhadze. Inwazję aut na centrum tego miasta zaczęto ograniczać od przekształcania ulic w deptaki, najpierw głównej arterii śródmiejskiej Stroeget (w 1962 r.). Jeszcze 40 lat temu w stolicy Danii samochody stały w długich korkach, obecnie już przeszło połowa jej mieszkańców przemieszcza się do pracy i szkoły na rowerach, kilka procent pieszo, a jedna trzecia używa transportu publicznego. W półmilionowej Kopenhadze jest obecnie blisko 600 km ścieżek rowerowych i wciąż powstają kolejne. (Pierwszą z nich zbudowano już w 1892 r., gdy w mieście było ledwie 2,5 tys. rowerów). W całej Danii na głowę statystycznego Duńczyka przypadają prawie dwa rowery. Każdy skład metra czy miejskiej kolejki musi mieć wagon dla cyklistów, a każda taksówka - stojak na dwa rowery. Istniejący system wypożyczania miejskich jednośladów przez całe lata funkcjonował za darmo.

${ }^{13}$ Wypowiedź na spotkaniu w Warszawie cyt. za: Ł. Długowski, Niech odżyją nasze miasta, „Gazeta Wyborcza”, 11-12.05.2013.

14 Wywiad z J. Gehlem, „Gazeta Wyborcza”, 15.11.2013. 
J. Gehl jest także zwolennikiem nie modernistycznego, lecz „humanistycznego planowania" i przekształcania miast, niskiej zabudowy, projektowania i budowania „na ludzką skalę". Jego zdaniem, takie modernistyczne miasta jak Brasilia najlepiej wyglądają z lotu ptaka (tak jak najlepiej z satelity czy na mapie wygląda warszawski Gocław, z symetrycznymi pętlami ulic), a nie z perspektywy pieszego, podczas gdy „człowiek ogląda świat horyzontalnie, z poziomu wzroku”. Z kolei w miastach bez wieżowców - takich jak Kopenhaga czy pozbawiona na dodatek samochodów Wenecja - ulice zachęcają do spacerów, spotykania się z innymi, przesiadywania w kawiarnianych ogródkach. W niektórych miastach, gdzie w śródmieściu są drapacze chmur, jak w Vancouver - zwraca uwagę J. Gehl - wieże są wycofane, wyrastają z niższego podium, zaś przy samych ulicach znajduje się co najwyżej kilkupiętrowa zabudowa ${ }^{15}$.

\section{Erozja przestrzeni publicznej w Warszawie - kilka znamiennych trendów i ich ilustracje}

Na ile wymienione powyżej zalecenia urbanistów urzeczywistnia dziś Warszawa? Historia dynamicznego rozwoju stolicy Polski w ostatnich dwóch dekadach to w znacznym stopniu opowieść także o tym, jak to, co publiczne i planowe, często przegrywało z tym, co prywatne i żywiołowe. Jak szersze i długofalowe interesy wspólnoty lokalnej bywały w praktyce wypierane przez wąskie i doraźne racje rynkowe czy komercyjne. Wskazane poniżej tendencje oraz ilustrujące je przytoczone tu niektóre przykłady empiryczne pokazują w sumie marną jakość i niedostatek przestrzeni publicznych w Warszawie.

Trudno zarazem w tym kontekście nie zauważyć, że wiele problemów, dylematów i kontrowersji dotyczących tworzenia przestrzeni miejskiej w Warszawie w tym okresie odnosi się w równej mierze do procesów zachodzących w innych krajowych i zagranicznych aglomeracjach, a także do współczesnej polityki publicznej w ogóle. W tym sensie polityka warszawska to często polska polityka publiczna w pigułce. Podobne kwestie, mankamenty, schorzenia, bolączki i słabości w kształtowaniu wspólnej przestrzeni występują na obu poziomach.

Przykładowo, okazywana w trakcie minionych ośmioletnich rządów Platformy Obywatelskiej i PSL (2007-2015) - znana pod hasłem „polityki ciepłej wody w kranie” - niechęć władzy państwowej do podejmowania trudnych wyzwań i reform, do konstruowania strategicznych wizji oraz ich realizowania w szerokim dialogu

${ }^{15}$ Szerzej zob. J. Gehl, Życie między budynkami. Używanie przestrzeni publicznych, Wydawnictwo RAM, Kraków 2009. 
z obywatelami i fachowcami z różnych dziedzin polityki publicznej, znajdowała nieraz swój odpowiednik w swoistej indolencji, niedostatku woli politycznej czy oportunistycznych obawach stołecznego ratusza przed stosownym porządkowaniem przestrzeni miejskiej z pomocą mieszkańców i ekspertów najróżniejszych specjalności.

\section{Deficyt strategii i planowania}

Brakowi koherencji, niedostatecznej spójności polityki publicznej w skali całego kraju odpowiada deficyt całościowego myślenia i zintegrowanego działania w przestrzeni miejskiej Warszawy. Krytycy wskazują na odczuwalną nieobecność długofalowej strategii rozwoju stolicy ${ }^{16}$. Dopiero niedawno rozpoczęła się dyskusja nad zarysem kompleksowej wizji rozwoju miasta w perspektywie $2030 \mathrm{r}$. Zwraca jednak uwagę dotychczasowy niedostatek strategicznego, urbanistycznego, a nierzadko i jakiegokolwiek planowania, które wciąż często uważa się za socjalistyczny relikt i przeżytek. Wielu rodzimym politykom procedura ta nadal kojarzy się z komuną, chociaż od dawna jest przecież szeroko praktykowana w większości rozwiniętych krajów zachodnich, zaś w Polsce była popularna nie tylko w czasach PRL, ale i w międzywojniu, także - a może przede wszystkim - w kontekście zarządzania dużymi miastami.

Dziś brakuje w Warszawie miejscowych planów zagospodarowania przestrzennego, zamiast nich wydawane są zgody na tymczasowe rozwiązania. W wielu miejscach mamy do czynienia ze zlepkiem warunków zabudowy, zapisami zamiarów poszczególnych inwestorów, które nieraz wykluczają się nawzajem. Wiąże się z tym swoista „patchworkowość” projektów i działań oraz chaotyczność zabudowy, której poszczególne elementy (wieżowce, mniejsze domy, odbudowane zabytki) jakoś słabo „sklejają się" w jedną całośćc ${ }^{17}$. Zdaniem wielu specjalistów, obecne regulacje dotyczące planowania przestrzennego utrudniają sensowne planowanie, $z$ drugiej zaś strony przepisy poświęcone np. reklamie nie przeszkadzają jej nadmiarowi, czyli tzw. szyldozie.

W opinii Ch. Montgomery'ego, kanadyjskiego pisarza i aktywisty miejskiego, autora książki Miasto szczęśliwe. Jak zmienić nasze życie, zmieniając miasto (2015), sytuacja panująca w Warszawie, ze względu na podobną nieobecność planowania

16 J. Rutkiewicz, architekt, urbanista i były burmistrz warszawskiego Śródmieścia (1990-1994) obecnym władzom miasta wystawia następującą cenzurkę: „W ratuszu potrafią już prowadzić grę w miasto, ale brakuje stratega”, „Gazeta Wyborcza”, 11.03.2016.

${ }_{17}$ To jeden z głównych grzechów polityki miejskiej w stolicy, wyeksponowany w książce znanego urbanisty. K. Domaradzki, Przestrzeń Warszawy. Tożsamość miasta a urbanistyka, Muzeum Powstania Warszawskiego, Warszawa 2016. Autor przywołuje w tym kontekście zabawne i sugestywne, celnie opisujące ową słabość, określenie Mirona Białoszewskiego, dotyczące zabudowy jednego z centralnych miejsc warszawskiej Pragi: „ronda Wiatraczna budynki się nie trzymają”. 
i oddanie w pacht niemal całej przestrzeni zmotoryzowanym, jest bliskie wzorcom afrykańskim. Oznacza to, że „to silniejszy i bogatszy dyktuje warunki, czyje jest miasto i przestrzeń publiczna", zaś piesi, osoby niepełnosprawne, starsze i dzieci są skazywani na schodzenie do przejść podziemnych ${ }^{18}$.

Dobrą ilustracją mało planowego rozwoju Warszawy może być zwłaszcza niekontrolowany rozrost jej przedmieść (urban sprawl). Chaotyczna zabudowa rozlewa się dziś na peryferiach miasta, po polach i łąkach niczym tłusta plama, z racji niskiej pierwotnej gęstości zaludnienia - na obszarach z ledwie wyspową infrastrukturą. W latach 2007-2013 ponad połowa pozwoleń na budowę w stolicy wydawana była na inwestycje w strefie przedmieść, poza właściwą strefą miejską i funkcjonalnym śródmieściem. O kierunkach tej ekspansji decydują deweloperzy, którzy często budują w szczerym polu, tam gdzie kiedyś rosły kartofle i kapusta, gdyż tam grunty są najtańsze. Następnie z niemałym zyskiem sprzedają wybudowane lokale mieszkalne, zaś samorządowym władzom publicznym wystawiają słone rachunki za drogi, działki pod szkoły czy przedszkola. Chaotyczność rozbudowy na obrzeżach miasta pogłębia problemy komunikacyjne. Zakorkowane trasy wylotowe to koszty społeczne (strata czasu z powodu długich dojazdów do centrum) i finansowe (spalone paliwo, zużycie pojazdów). Wadom rozproszonej sieci osiedleńczej nie jest w stanie skutecznie zaradzić niedomagający transport publiczny.

Przykładem mogą być tu rozległe tereny w dzielnicy Białołęka, która w ostatnich dwóch dekadach przekształciła się w jedną wielką miejską sypialnię. Konglomerat osiedli z bardzo kiepskim dojazdem, przeciążoną siecią wodociągowo-kanalizacyjną i zatłoczonymi placówkami wychowawczo-edukacyjnymi powstał trochę jak nieplanowane czy niechciane dziecko. W bardzo nielicznych tu szkołach uczniowie pobierają naukę na trzy zmiany, brakuje też przedszkoli i żłobków.

Ilustracją bezplanowego działania znacznie bliżej centrum miasta może być duża część dzielnicy Służewiec, gdzie bez żadnego planu zagospodarowania nastąpiła ogromna i stosunkowo szybka przemiana jednej monokultury (przemysłowej) na drugą (biurową). Dziś jest to największe „zagłębie biurowe” stolicy, prześmiewczo zwane powszechnie Mordorem ${ }^{19}$. Przez ostatnich 20 lat powstał tu ponad milion $\mathrm{m}$ kw. biur, czyli więcej niż jedna piąta całej istniejącej obecnie powierzchni biurowej w Warszawie. Stanowi to zarazem prawie jedną trzecią wszystkich zasobów biurowych w pozostałych miastach Polski (szacowanych w sumie na 3,5 $\mathrm{mln} \mathrm{m} \mathrm{kw}$.) ${ }^{20}$.

18 Wypowiedź na spotkaniu w Warszawie cyt. za: D. Bartoszewicz, Warszawa afrykańska, „Gazeta Wyborcza”, 17-18.11.2015.

19 Ostatnio zaczyna z nim konkurować już Wola, zwłaszcza w okolicach przystanków drugiej linii metra.

${ }^{20}$ M. Wojtczuk, Warszawa szybko rośnie, „Gazeta Wyborcza”, 5.05.2016. 
Do pracy dojeżdża tu dziennie nawet ok. 100 tys. ludzi (dane z 2015 r.), co w ciągu dnia powoduje ogromne korki uliczne oraz ścisk w autobusach i tramwajach, nawet na schodach wyjściowych z metra, ale po godz. 17 większa część okolicy jest już martwa. Na terenie tym nie ma placów, skwerów czy obiektów kulturalnych, jeśli nie liczyć multipleksu w galerii handlowej. Brakuje chodników, ścieżek rowerowych; dość przypadkowa zieleń jest zaniedbana. Zaległości w sieci komunikacyjnej mają być tu reaktywnie odrabiane dopiero w najbliższych latach: w 2018 r. do trzech pasów poszerzona zostanie przelotowa ul. Marynarska, zaś do 2020 r. ma powstać linia tramwajowa wzdłuż al. Wilanowskiej od Galerii Mokotów do stacji metra Wilanowska.

Innym przykładem co najmniej częściowej porażki planistycznej może być Miasteczko Wilanów ${ }^{21}$, którego praktyczna realizacja daleko rozminęła się z pierwotną, bardzo obiecującą, szlachetną i piękną wizją zbudowania na podstołecznych polach i łąkach wielkiego osiedla-ogrodu na miarę XXI w. Tymczasem w planie zagospodarowania tego terenu (w odróżnieniu np. od PRL-owskiego Ursynowa czy przedwojennego Żoliborza) zabrakło ostatecznie programu społecznego, tzn. nie przewidziano miejsca na szkoły, przedszkola, placówki kulturalne czy przychodnie zdrowia, co jest dziś przez mieszkańców mocno odczuwalne. Trwa tam dopiero budowa pierwszej podstawówki dla 500 uczniów, zaś wykup od deweloperów gruntu przez dzielnicę pod bardzo potrzebną drugą tego rodzaju szkołę napotyka przeszkody ze strony prywatnych właścicieli. Dlatego władze dzielnicy wystąpiły ostatnio do ratusza o punktowe zmiany planu zagospodarowania za pomocą „łatek” - mikroplanów, które wykluczałyby możliwość budowy czegokolwiek innego niż placówki oświatowe na upatrzonych pod podobne inwestycje działkach ${ }^{22}$.

Okazało się ponadto, że w tym wielkim deweloperskim kompleksie osiedli, gdzie zameldowanych jest już ponad 10 tys. osób, wciąż prawie nie ma drzew, nie mówiąc już o parkach. Są tylko wąskie i zaniedbane paski zieleni, zaś przy zarośniętym glonami, nie pielęgnowanym przez nikogo kanałku stoi kilka ławek. Dominuje gęsta zabudowa, sieć ulic zastawionych autami (bo miejsca w podziemnych garażach są drogie) jest rachityczna, jedynym szerszym traktem jest Aleja Rzeczypospolitej, przy której góruje nad okolicą, położona w samym sercu Miasteczka, monumentalna Świątynia Opatrzności Bożej²3. W maju 2016 r. na granicy otaczającego ją rozległego

${ }^{21}$ Miasteczko zwane jest potocznie „lemingradem”. Nazwa pochodzi od „lemingów”, jak przez prawicowych publicystów złośliwie bywają określani przedstawiciele yuppies, czyli młodej klasy średniej, nowego mieszczaństwa głosującego najczęściej na PO (co pokazują zresztą wyniki wyborów odnotowywane $\mathrm{w}$ Wilanowie, gdzie w porównaniu z innymi dzielnicami Warszawy najwyższy procent mieszkańców oddaje głosy na Platformę).

${ }_{22}$ M. Wojtczuk, Wilanów odbija działki pod szkoły, „Gazeta Wyborcza”, 7-8.05.2016.

${ }^{23}$ Zwana szyderczo przez niektórych warszawiaków „grzmotem” opatrzności z betonu lub - z racji kształtu kopuły - wielką wyciskarką do cytryn. Prześmiewcy podpowiadają, że w świątyni tej można się 
terenu zaczął wyrastać blisko dwumetrowy płot. W reakcji na niekonsultowaną wcześniej z mieszkańcami i władzami miejskimi budowę ogrodzenia przez kurię warszawską, wiceprezydent stolicy Jacek Wojciechowski tak tłumaczył dziennikarzowi swój sceptyczny stosunek do tej inwestycji: „Jedna z podstawowych różnic między miastem a wsią jest taka, że w mieście wzdłuż ulicy stoją domy tworzące pierzeję, a na wsi płoty. Pola Wilanowskie wsią już nie są. Nie widzę potrzeby grodzenia Świątyni Opatrzności”24.

\section{Ruderyzacja miejsc wspólnych}

Fakt, że w wybudowanym od podstaw w III Rzeczypospolitej wielotysięcznym Miasteczku Wilanów nie ma żadnego placu publicznego, wydaje się charakterystyczny dla tendencji określających w ostatnim okresie rozwój Warszawy. Tak samo jak za znamienne wypada uznać to, że po 1989 r. żaden tego typu większy plac ani park (na skalę choćby tego na Szczęśliwicach czy na Polu Mokotowskim) nie powstał w żadnej innej części miasta. Wiele miejskich placów zbudowanych wcześniej (jak np. Defilad, Konstytucji, Powstańców Warszawy czy Teatralny) zamieniono tymczasem w parkingi. Odziały banków, drogie restauracje i ekskluzywne sklepy zaczęły wypierać z ulic księgarnie, biblioteki, tańsze kawiarenki, bary, kluby itp. Czy można w związku z tym mówić o zanikaniu, dewastowaniu, degradacji i ogólnym regresie w Warszawie wspólnej przestrzeni miejskiej?

Interesująca pod tym względem wydaje się transformacja i obecny stan ścisłego centrum stolicy, a zwłaszcza otoczenia Pałacu Kultury i Nauki, gdzie kryje się prawdopodobnie stosunkowo największy potencjał na uformowanie się nowoczesnego ośrodka życia publicznego i kulturalnego miasta.

Przyjrzyjmy się najpierw przemianom, jakie zachodziły po upadku PRL na największym placu Warszawy, czyli na Placu Defilad. Kiedyś było to miejsce wielkich pochodów (nie tylko pierwszomajowych) oraz zgromadzeń, jak to w październiku 1956 r. z udziałem powracającego do władzy Władysława Gomułki czy też msza święta z okazji pielgrzymki papieskiej Jana Pawła II w Polsce w 1987 r. Odbywały się tu popularne kiermasze księgarskie, wydarzenia kulturalne i rozrywkowe, często o wymowie propagandowej (jak np. doroczne święto partyjnej gazety „Trybuny Ludu" w latach 70.). Po 1989 r. plac był wykorzystywany na większe imprezy masowe

pomodlić, aby nastąpiły jakieś zmiany przybliżające to osiedle choćby w skromnym stopniu do pierwotnej wizji miasta-ogrodu.

${ }^{24}$ Cyt. za: M. Wojtczuk, Świątynia za płotem, „Gazeta Wyborcza”, 21-22.05.2016. 
już tylko sporadycznie - na Finał Wielkiej Orkiestry Świątecznej Pomocy, miejski sylwester czy strefę kibica podczas Euro 2012. Zaraz po przełomie ustrojowym cały Plac Defilad przekształcił się w gigantyczny bazar z towarem oferowanym na specyficznych straganach - w tzw. szczękach i na łóżkach polowych. Pojawiły się następnie dwie szpetne targowe hale blaszaki, zamknięte i rozebrane dopiero w 2009 r., zresztą przy wielkich protestach kupców.

Dziś śladem po dawnych czasach PRL jest tylko kamienna trybuna, wokół której rozlokowano gigantyczny parking, prymitywny minidworzec prywatnych busów oraz budy z zapiekankami i innym asortymentem, których działalność kwitnie zwłaszcza na prywatnej działce u zbiegu ul. Marszałkowskiej i Świętokrzyskiej. Wszystko to, w chaosie i - co tu dużo mówić - dostrzegalnym brudzie, trwa w przedłużającym się oczekiwaniu na budowę nowoczesnych siedzib dwóch placówek kulturalnych: Muzeum Sztuki Nowoczesnej oraz TR Warszawa ${ }^{25}$. Przed nimi przewidywane jest urządzenie pół placu - wybetonowanego bądź zadrzewionego (tego jeszcze nie przesądzono), połowicznego w każdym razie, bo pozbawionego granicznej pierzei od południowej strony, ze względu na roszczenia majątkowe do znajdujących się tam działek.

Obok, na rogu Marszałkowskiej i Alej Jerozolimskich, znajduje się tzw. patelnia, prowizoryczny placyk między wejściem do stacji metra Centrum a wylotem przejścia podziemnego pod Rondem Dmowskiego, ograniczony od południa i wschodu betonową ścianą. Z racji tego, że stanowi ważny i intensywnie wykorzystywany ciąg komunikacyjny, który trudno ominąć, stał się ulubionym miejscem akwizytorów, sprzedawców gadżetów i różnych dziwacznych akcesoriów, ulicznych grajków, bezdomnych (którym kilka razy w tygodniu wydawane są tu posiłki), kieszonkowców i zbieraczy podpisów na listach polityków kandydujących w wyborach. Jest to więc także rodzaj mini Hyde Parku, który upodobali sobie zwłaszcza propagujący tu swoje poglądy konserwatyści i prawicowcy - korwiniści, kukizowcy czy przeciwnicy aborcji i adopcji dzieci przez pary homoseksualne. Od 2010 r. co środę odbywają się tu także spotkania organizowane przez ruch tzw. Kościoła Ulicznego, w trakcie których pod dużym drewnianym krzyżem modlą się razem zielonoświątkowcy, baptyści, prawosławni i katolicy. Trudno byłoby zatem stwierdzić, że jest to miejsce nieegalitarne, kogoś z góry wykluczające. Chcąc nie chcąc, pełni więc ono na swój sposób rolę skromnej publicznej agory.

Kontrastuje z tą zaludnioną na co dzień, acz chaotyczną i w sumie mało estetyczną przestrzenią - pustka, jaka panuje obecnie w zrewitalizowanym niedawno niemałym kosztem miejscu publicznym, jakim jest pobliski Pasaż Wiecha, po drugiej stronie

${ }^{25}$ Wedle projektu amerykańskiego architekta T. Phifera, mają to być dwie proste bryły: duża i biała (MSN) oraz mniejsza i ciemna (gmach teatru) bliżej PKiN, obie połączone zadaszonym placykiem. 
ul. Marszałkowskiej. Zwany pierwotnie Śródmiejskim, połączył w 1969 r. w bardzo udany sposób modernistyczne Domy Towarowe „Centrum” z częściowo XIX-wieczną zabudową na ich zapleczu. Deptak zaprojektowany przez Zbigniewa Karpińskiego, wyraźnie inspirującego się wzorcami skandynawskimi, po niedawnej przebudowie całkiem jednak zmienił oblicze i charakter. Kiedyś był to nowoczesny salon stolicy, jednocześnie wielkomiejski i kameralny. Miał ludzką skalę, stały tu ławki i gazony z małymi krzewami, były kwietniki, fontanny i ażurowe daszki, na deptaku tętniło życie.

$\mathrm{Z}$ jednej strony ciąg ograniczały szerokie witryny magazynów handlowych Wars, Sawa i Junior, z drugiej zaś był popularny bar i letnia kawiarnia Zodiak (dziś działają tu fast foody), kupujących przyciągał salon Mody Polskiej, dużą frekwencją cieszyła się również niemal kultowa winiarnia Amfora. Przed premierowym kinem Relax ustawiały się kolejki, w jego podziemiach działał Teatr Mały, filia Narodowego, nieopodal był klub studencki Hybrydy. „Teraz - mówi prof. Waldemar Baraniewski, historyk architektury z ASP - to zruderyzowana przestrzeń w centrum: pusta, opresyjna, z dziwacznymi latarniami przypominającymi elektrownie wiatrowe"26.

Te latarnie to fantomy wielkich słupów, które po modernizacji miały podpierać ogromny dach ze szkła, ale ostatecznie ten pomysł zarzucono. Po usunięciu pierwotnej zieleni i tzw. małej architektury z pasażu uszło życie. Nie pomogło urządzenie tu alei gwiazd (sic!). Na trotuarze swoje gwiazdy mają m.in. Penelope Cruz i Marilyn Monroe, nie ma jednak nic, co przypominałoby o patronie miejsca, wielkim patriocie Warszawy - Stefanie Wiecheckim-Wiechu. Warszawiakom to miejsce kojarzy się obecnie z pustynią, przeciągami i wielkim wygonem. „Po likwidacji daszków odsłoniła się skromna mieszkanióweczka PRL-u. I nagle się okazało, że przy salonie są bloki i elewacje jak w Pcimiu” - twierdzi Andrzej Kaliszewski, współautor dwóch mieszkalnych wieżowców przy Pasażu Wiecha ${ }^{27}$. Zdaniem znanego pisarza i historyka W. Karpińskiego, syna projektanta tego pasażu, to najwspanialsze w całym architektonicznym dorobku dokonanie ojca zostało po prostu zdewastowane ${ }^{28}$.

\section{Grodzenie, czyli segregacja}

Przejawem niechęci do traktowania przestrzeni miejskiej jako wspólnego dobra jest upowszechnianie się swoistego „myślenia zagrodowego”. Z przestrzeni publicznej wydzielane są zatem - prawnie lub bezprawnie - przestrzenie prywatne, zwykle

${ }^{26}$ Wywiad z W. Baraniewskim, „Gazeta Wyborcza”, 14.11.2014.

27 Cyt. za: D. Bartoszewicz, Pasaż Wiecha - reaktywacja, „Gazeta Wyborcza”, 27.11.2014; W. Karpieszuk, Kiedyś było tu życie, teraz jak pustynia, „Gazeta Wyborcza”, 16.12.2013.

${ }^{28}$ Wywiad z W. Karpińskim, „Gazeta Wyborcza”, 2-3.04. 2016. 
pod pretekstem zwiększenia bezpieczeństwa mieszkańców. Te zamknięte enklawy dla bogatych, zwane też „wyspami luksusu”, pogłębiają jednak rozwarstwienie społeczeństwa. Kilka lat temu doliczono się w Warszawie ponad 400 ogrodzonych osiedli, podczas gdy w Berlinie tylko jedno, przy czym znajdujące się na obrzeżach miasta, zaś w Paryżu trzy. Trudno byłoby znaleźć w stolicy Polski nowe osiedle bez płotu, niestrzeżone przede wszystkim w ten sposób.

Warszawskie osiedle Marina Mokotów było w roku otwarcia (2005) - a raczej zamknięcia - największym w Polsce osiedlem ogrodzonym płotem. Badający tam relacje społeczne prof. Bohdan Jałowiecki, socjolog miasta z UW, zwrócił uwagę, że w ramach całego osiedla zaczęły powstawać dodatkowo płoty wewnętrzne, gdyż np. mieszkańcy apartamentów za półtora miliona dolarów nie chcieli dzielić przestrzeni publicznej z tymi, którzy kupili mieszkanie za jedynie pół miliona. Postanowili zatem się od nich dodatkowo odgrodzić29. Taka struktura mieszkalna przywodzi na myśl swoisty system śluzowy, szkatułkowy czy układ obronny znany ze starożytnych lub średniowiecznych miast, na które składały się: gród, podgrodzie, podpodgrodzie itd.

Przy okazji tej inwestycji doszło też do znamiennej „zdrady” dewelopera, który obiecał ludziom mieszkania w osiedlu zamkniętym, ale wynajął potem lokale także sklepom i zezwolił na korzystanie z nich osobom z zewnątrz. Mieszkańcy zaprotestowali, motywując to osłabionym poczuciem bezpieczeństwa, ale kierując się także niekoniecznie głośno artykułowaną argumentacją i uzasadnieniem: „Nie po to zapłaciłem tyle pieniędzy za luksusowe mieszkanie, żeby teraz byle kto szwendał się i włóczył pod moimi drzwiami czy oknami”. W rezultacie wzmocniono monitoring, zdwojono patrole ochroniarzy, zainstalowano dodatkowe kamery itp., wszystko po to, by zapewnić jeszcze większe poczucie bezpieczeństwa. Pomimo podobnych zabiegów okazuje się ono jednak często iluzoryczne.

Rozważając kwestię realnych przyczyn tworzenia enklawowych „wysp luksusu” w miastach dla ludzi bogatych, Filip Springer w swoim znanym zbiorze reportaży o polskiej przestrzeni ${ }^{30}$ cytuje m.in. Zygmunta Baumana, który źródła skłonności do stawiania płotów dostrzega w zjawisku nazywanym przez siebie miksofobią. Polega ono na odreagowywaniu różnorodności typów ludzkich i stylów życia, z jakimi stykamy się na zatłoczonych ulicach współczesnych miast i w większości „zwyczajnych” dzielnic $^{31}$. Przytacza także opinię na ten temat Stefana Kuryłowicza, generalnego projektanta wspomnianego wyżej osiedla Marina Mokotów: „Popularność osiedli zamkniętych bierze się tak z potrzeby bezpieczeństwa, jak i z chęci przebywania

${ }^{29}$ Wywiad z B. Jałowieckim, „Gazeta Wyborcza”, 15-16.11.2014.

${ }^{30}$ F. Springer, Wanna z kolumnadą. Reportaże o polskiej przestrzeni, Wydawnictwo Czarne, Wołowiec 2013.

${ }^{31}$ Z. Bauman, Razem osobno, Wydawnictwo Literackie, Kraków 2003, s. 230-231. 
w otoczeniu zadbanym, a nie zapuszczonym, co jest niestety cechą większości osiedli budowanych w przeszłości" ${ }^{32}$. Cieszą się one większą estymą wśród klientów, którzy najczęściej domagają się stawiania płotów. To raczej potrzeba mentalna niż realna, bardziej motywacja czysto psychologiczno-prestiżowa niż oparta na racjonalnych przesłankach, co skrzętnie wykorzystują deweloperzy, podbijając przy okazji cenę wznoszonych nieruchomości, choć niektórzy z nich woleliby ograniczyć koszty budowy, rezygnując z ogradzania osiedli.

Jak przekonują socjologowie, miasta, gettoizacja, obsesja wydzielania prywatnych kawałków ze wspólnej przestrzeni, odgradzanie się i separowanie ludzi zamożnych od biednych bądź tych, którym powodzi się gorzej, w imię iluzorycznego bezpieczeństwa - to symptom potrzeby podkreślania swojego wyższego statusu, ale i niskiego poziomu zaufania społecznego i poczucia bezpieczeństwa ${ }^{33}$. Jednak zapewnienie bezpieczeństwa to w dużym stopniu fasada i fikcja, bo grodzenie osiedli wcale nie chroni przed włamaniami, na co wskazują doświadczenie i wyniki badań empirycznych, przeprowadzanych nie tylko w USA ${ }^{34}$.

Aspekty międzyklasowego sporu pomiędzy bogatszymi i biedniejszymi warszawiakami niektórzy widzą w kontrowersjach i napięciach, jakie wywołał plan nowej przeprawy mostowej przez Wisłę, która ma połączyć zamożny i nobliwy Żoliborz z uboższym, robotniczym Targówkiem. Przeciwko projektowi budowy mostu Krasińskiego w 2016 r. zdecydowanie zaprotestowali mieszkańcy pierwszej z wymienionych dzielnic. Oponenci tej inwestycji wskazują przede wszystkim, że w zaprojektowanym pierwotnie kształcie stanowiłaby ona kolejną zachętę do poruszania się po Warszawie prywatnymi autami, korkując przy tym w szczególności jeden z ładniejszych (i stosunkowo wolnych jeszcze od wielkomiejskiego zgiełku) fragmentów stolicy. Główny ciężar postulatów i żądań położony więc został na takie zmodyfikowanie projektu, które pozwoliłoby skierować zasadniczy ruch pojazdów z mostu bezpośrednio na Wisłostradę oraz odciąć, zabezpieczyć w ten sposób Żoliborz przed masowym tranzytem w stronę Powązek.

Część komentatorów wskazuje jednak, że niezależnie od zagrożenia hałasem, korkami i spalinami, jeden z istotnych, acz rzadziej, mniej otwarcie i słabiej

32 Cyt. za: A. Theiss, Jak się żyje w osiedlu zamkniętym, „Architektura Murator” 2008, nr 2, s. 37.

${ }^{33}$ Gettoizacja polskiej przestrzeni miejskiej, red. B. Jałowiecki, W. Łukowski, Wydawnictwo Naukowe Scholar, Warszawa 2007; J. Gądecki, Za murami. Osiedla grodzone w Polsce - analiza dyskursu, Wydawnictwo Uniwersytetu Wrocławskiego, Wrocław 2009.

${ }^{34}$ M.in. F. Springer, op.cit., przytacza na to różne dowody, cytując także źródła zagraniczne, np. E.J. Blakely, G.M. Snyder, Fortress America: Gated Communities in the United States, Brookings Institution Press, Washington 1999; R. Atkinson, O. Smith, An Economy of False Securities? An Analysis of Murders inside Gated Residential Developments in the US, "Crime Media Culture" 2012, Vol. 8, No. 2. Co więcej, ci ostatni autorzy dowodzą, że ogrodzenie osiedla, paradoksalnie, zwiększa nawet ryzyko napaści na osoby przychodzące tam z zewnątrz. 
artykułowanych publicznie, motywów tego oporu da się sprowadzić do tego, że stara inteligencja i nuworysze z kameralnej tzw. dobrej dzielnicy najwyraźniej nie życzą sobie „fizycznego zbliżenia” i częstszych kontaktów (ułatwionych dzięki przeprawie mostowej) ze „słoikami” (czyli młodymi przyjezdnymi warszawiakami w pierwszym pokoleniu) oraz „dresiarzami” z blokowisk po drugiej stronie Wisły. Mogłoby to bowiem prowadzić do jakiegoś symbolicznego mezaliansu. Na zorganizowanej w jeden z lutowych weekendów kilkusetosobowej demonstracji przeciwników mostu pojawiła się tymczasem także grupka kontrmanifestantów z Targówka, z transparentem: „Wisła nie morze - połączmy się z Żoliborzem"35.

Pewien paradoks polega tu na tym, że - jak przypomina jeden z publicystów - przedwojenny Żoliborz był wizjonerskim projektem socjalistów z Warszawskiej Spółdzielni Mieszkaniowej, którzy chcieli zbudować nowoczesną dzielnicę dla robotników i inteligencji, bez podziałów klasowych. Co zresztą udało się tylko częściowo, bo obok niewielu kolonii WSM, zbyt drogich dla prostych robotników, powstały osiedla dla oficerów, urzędników, dziennikarzy czy profesorów. Po wojnie Żoliborz stał się enklawą dla inteligencji o PPS-owskich korzeniach, zaś okres po 1989 r. przyniósł skokową wręcz gentryfikację dzielnicy. W obecnych protestach przeciwko mostowi A. Leszczyński upatruje niemal „czysty przypadek walki klasowej o przestrzeń”, co przy okazji nasuwa mu przypuszczenie, że „założyciele WSM przewracają się w grobach" ${ }^{36}$.

W rozwiniętych państwach zachodnich niwelowanie podziałów klasowo-warstwowych poprzez egalitarne mieszanie mieszkańców w przestrzeni, także w ramach tego samego budynku, i zbliżanie ich w ten sposób do siebie, znane jest pod nazwą social mixing. W Helsinkach, Kopenhadze czy Hamburgu luksusowe apartamentowce nierzadko stawiane są tuż obok bloków komunalnych, aby po sąsiedzku żyły różne grupy mieszkańców, chociaż nie zawsze podobne przedsięwzięcia udają się na dłuższą metę. Tymczasem we współczesnej Polsce - jak twierdzi J. Gądecki z SGH - proces ten „byłby raczej trudny do przełknięcia, bo wciąż jesteśmy społeczeństwem na dorobku i nadal budujemy naszą rzeczywistość na kontrze do socjalizmu”37. Dodajmy, także w kontrze do sytuacji i praktyk znanych z czasów PRL, uwiecznionych m.in. w popularnym serialu komediowym Alternatywy 4, kiedy to na tym samym piętrze w bloku komunalnym czy spółdzielczym świadomie kwaterowano obok siebie

35 Żoliborz przeciw mostowi, „Gazeta Wyborcza”, 22.02.2016.

36 A. Leszczyński, Klasowy opór Żoliborza, „Gazeta Wyborcza”, 20-21.02.2016.

37 Wywiad z J. Gądeckim i B. Jałowieckim, „Gazeta Wyborcza”, 15-16.11.2014 (tam też więcej o nieudanych doświadczeniach w praktykowaniu social mixing w Londynie i Paryżu). Argumentacji J. Gądeckiego można by przypisać wątpliwe w tym wypadku myślenie stadialne, tzn. próbujące przekonywać, że coś, co na obecnym etapie wydaje się nieakceptowalne, w późniejszym okresie może stać się pożądane i realne. 
niewykwalifikowanych robotników i wykształconych inteligentów. Dziś zamieszkałe w enklawach „elity”, pomne owego przymusowego sąsiedztwa, najwyraźniej nie chcą żyć obok „hołoty”, wolą odgradzać się od plebsu, pospólstwa czy proletariatu.

\section{Urynkowienie i komercjalizacja}

W radykalnym myśleniu wolnorynkowym przestrzeń publiczna, porządek urbanistyczny i architektura stają się prostym przedłużeniem rynku nieruchomości, zakładnikami bezlitosnej, czystej ekonomii. O ich kształcie mają rozstrzygać nie racjonalne planowanie, dobry projekt i szlachetne założenia estetyczne, lecz wąski rachunek ekonomiczny. Ważniejsze od tego, co powstaje na deskach kreślarskich profesjonalnych urbanistów i ambitnych architektów, jest to, co się rodzi w głowach (na ogół liczących na szybki zysk) inwestorów i deweloperów, a wynika to z parametrycznych algorytmów, z liczb zawartych w arkuszach kalkulacyjnych Excela.

Najbardziej rzucającym się w oczy, spektakularnym przejawem komercjalizacji warszawskiej przestrzeni jest skażenie wizualne, schorzenie nazywane potocznie „reklamozą” lub „szyldozą”. Chodzi o natłok krzykliwych, szpetnych, wręcz szmatławych reklam, zwłaszcza wielkoformatowych, osaczających i bombardujących przechodniów oraz zalepiających coraz więcej miejskiej przestrzeni. Przytłaczające wszystko dookoła, nierzadko ohydne megapłachty i banery na fasadach budynków, nachalne billboardy na stelażach i przyczepach, pooklejane słupy plakatowe, przystanki i latarnie - wszystko to składa się na prawdziwy zalew i orgię śmieciowego marketingu. Warszawa bije pod tym względem na głowę inne, nawet te największe europejskie stolice. W $2013 \mathrm{r}$. największa siatka reklamowa miała tu powierzchnię $164 \mathrm{~m}$ kw., podczas gdy w Paryżu tylko $8 \mathrm{~m}$ kw. W stolicy Polski było wówczas 8,5 tys. samych tylko billboardów, zaś w stolicy Francji dużo mniej, bo zaledwie 2,3 tys. ${ }^{38}$.

Dobrym przykładem omawianej tendencji może być daleko posunięte zmarketyzowanie (urynkowienie) hali Dworca Centralnego, architektonicznego arcydzieła Arseniusza Romanowicza. Dworzec ten przekształca się stopniowo w dostawkę do firm, które coraz agresywniej zaburzają i anektują kawałek po kawałku jego przestrzeń. Przez całe lata z powodu wielkich banerów reklamowych prawie nie widać było jego architektury z zewnątrz. Natomiast zagracanie hali głównej, którą zaplanowano jako wysoką i pustą, rozpoczęło się stosunkowo niedawno. Najpierw, przed Euro 2012, stanęły tam szklane kubiki handlowe, które jednak, jako mało funkcjonalne, wkrótce

38 „Gazeta Wyborcza”, 15.11.2013. 
zlikwidowano. Wdrażanie ambitnych planów komercjalizacyjnych $\mathrm{PKP}^{39}$ zmieniło następnie wygląd hali niemal nie do poznania, gdy na początku 2016r. zaczęła ona przypominać w istocie nie dworzec, lecz wnętrze galerii handlowej.

Bar McDonald's na galerii wschodniej został połączony powietrznymi pomostami z magazynem Biedronka na galerii zachodniej. Nowa antresola, pod którą zlokalizowano kilka dodatkowych punktów gastronomicznych i na którą prowadzą schody ruchome, ma kształt monstrualnego węża bądź ameby, która rozłazi się na wszystkie strony i zasłania teraz podróżnym nie tylko kasy główne, ale i dużą część okien. Dlatego też konieczne stało się zainstalowanie w środku ogromnych lamp, przypominających łyżki, wrzeciona lub kije do golfa. Całość przebudowy, która może razić poczucie gustu i smaku, wzbudza dziś kontrowersje nie tylko ze względów estetyczno-stylistycznych. Nie ma natomiast wątpliwości, że ułatwiony dostęp z parteru na górny poziom hali poprawi obroty tamtejszym najemcom.

Ilustracją zagrożenia komercjalizacją znacznie większego terenu miasta może być potencjalny skandal ochrzczony mianem „Szarytki Development”. Pod tym kryptonimem kryje się ujawniony w 2015 r. zamiar rozparcelowania i przeznaczenia pod zabudowę blisko pięciohektarowego, zabytkowego ogrodu klasztornego sióstr szarytek (Zakład św. Kazimierza Zgromadzenia Sióstr Miłosierdzia) na warszawskiej skarpie. Grunt ten podarowała zakonnicom w połowie XVII w. królowa Maria Ludwika Gonzaga, by poprowadziły tam gospodarstwo na potrzeby działalności charytatywnej. Bynajmniej więc nie po to, by wykorzystały go w celach... inwestycyjno-deweloperskich. Pełnomocnikiem zakonnic w tej sprawie okazał się znany lobbysta warszawskich deweloperów, który już wielokrotnie odwoływał się od decyzji wojewódzkiego konserwatora zabytków o wpisaniu tego terenu do rejestru zabytków. Dopuszcza ona zbudowanie tam tylko niewielkiego obiektu typu przedszkole lub dom opieki, ale nie biurowców lub apartamentów mieszkalnych. Eksperci szacowali roczne dochody $\mathrm{z}$ realizacji projektu inwestycyjnego o tym drugim charakterze na kilkanaście mln zł rocznie. W razie jego realizacji malownicza półwiejska enklawa w środku Warszawy, o dużej wartości historycznej i artystycznej, przestałaby praktycznie istnieć.

Osobnym problemem jest dzika reprywatyzacja, okraszana już czasem mianem „po warszawsku”. Polega ona coraz rzadziej na odzyskiwaniu mienia przez przedwojennych właścicieli lub ich spadkobierców, a coraz częściej na przejmowaniu go

39 Tak przedstawiała je w 2015 r. M. Zabłocka, dyrektor Departamentu Komercjalizacji w PKP SA, w branżowym piśmie „Rynek Kolejowy”: „Warszawa Centralna to przykład udanej komercjalizacji dworców kolejowych. Obecnie stopień wynajęcia powierzchni w obiekcie wynosi 93 proc. Przestrzeń handlowo-usługowa na tym dworcu zwiększy się jeszcze pod koniec roku, kiedy w hali głównej oraz remontowanych obecnie galeriach podziemnych pojawią się nowe lokale", cyt. za: D. Bartoszewicz, Biedronka Centralna klapa, „Gazeta Wyborcza”, 28.04.2015. 
przez zawodowych kupców roszczeń reprywatyzacyjnych, nierzadko różnego rodzaju spekulantów, naciągaczy i cwaniaków, którzy specjalizują się w nabywaniu roszczeń o bardzo wątpliwej wartości prawnej. Używają w tym celu rozmaitych podejrzanych i wymyślnych chwytów, np. popularnego triku „na kuratora z Karaibów”, który działa $\mathrm{w}$ imieniu byłych, ale od dawna już nieżyjących właścicieli ${ }^{40}$.

Majątki znacjonalizowane w Warszawie tuż po wojnie na mocy dekretu Bieruta z 1945 r. można odzyskiwać od połowy lat 90., ale kwestia ta nie została dotychczas uregulowana ustawą i zdarza się, że miasto oddaje w prywatne ręce wiele nieruchomości wartych miliony złotych bez wystarczających podstaw. Nie ma to wówczas nic wspólnego z wyrównywaniem historycznych krzywd, jest raczej wyłudzaniem publicznego mienia za pomocą różnych prawniczych sztuczek lub wręcz zwyczajnych przekrętów. Ostatnio ujawnionym głośnym przypadkiem tego rodzaju, ochrzczonym już w mediach największą aferą reprywatyzacyjną w stolicy w całej jej historii, był nieuzasadniony zwrot w 2012 r. trzem kupcom roszczeń działki przy PKiN wartej ponad $100 \mathrm{mln}$ zł. Grunt ten należał przed wojną do obywatela Danii i jako taki w rzeczywistości nie mógł podlegać roszczeniom, gdyż w PRL podpisano umowę, w ramach której zbiorczo wypłacono już temu państwu odszkodowania za znacjonalizowane nieruchomości Duńczyków, w tym za parcelę przy ul. Chmielnej 70 (taki był jej przedwojenny adres) $)^{41}$.

Nawet legalna reprywatyzacja miejskich parków, skwerów, szkół, przedszkoli czy innych obiektów użyteczności publicznej, w imię „świętego prawa własności”, likwidowanie ogródków działkowych, traktowanych jako przeżytek i socjalistyczny „obciach”, mogą wzbudzać wątpliwości z punktu widzenia ochrony interesu społecznego, stawianego najczęściej poniżej interesu indywidualnego. Specjaliści zauważają, że w III Rzeczpospolitej orzecznictwo polskich sądów w zakresie prawa administracyjnego i cywilnego (nie tylko w sprawach własnościowych dotyczących dekretu Bieruta) z reguły uznaje pierwszeństwo obywatela i prywatnego właściciela nad społeczeństwem czy wspólnotą. Tzw. dobro i majątek publiczny liczą się tu w znacznie mniejszym stopniu, jeśli w ogóle, co bywa interpretowane jako „wychylenie wahadła” w drugą stronę po częstym naruszaniu praw jednostek i eksponowaniu racji państwowych w długim okresie PRL ${ }^{42}$.

${ }^{40}$ I. Szpala, M. Zubik, Jak przejąć ogródki na Szweda z Karaibów, „Gazeta Wyborcza”, 10.06.2016.

${ }^{41}$ I. Szpala, M. Zubik, Dziwne przypadki reprywatyzacji, „Gazeta Wyborcza”, 29.04.2016; M. Wybieralski, Duma i przerażenie, „Gazeta Wyborcza”, 16.05.2016; M. Wybieralski, Ratusz wycisza aferę, „Gazeta Wyborcza", 1.06.2016.

42 Zob. np. opinię M. Bajki, dyrektora Biura Gospodarki Nieruchomościami w stołecznym ratuszu, w wywiadzie dla „Gazety Wyborczej”, 4-5.10.2014. 
Prawnik i konstytucjonalista W. Osiatyński, w kontekście - jak to określa - „zdemolowania Warszawy” w wyniku procesów reprywatyzacyjnych, do słabszych stron czy też porażek ustawy zasadniczej z 1997 r. (w przygotowaniu której, jako ekspert, notabene, walnie uczestniczył) zalicza zbyt silną ochronę w niej własności prywatnej, którą wyniesiono ponad społeczną gospodarkę rynkową. Wedle konstytucji, ta ostatnia ma się opierać najpierw „na wolności działalności gospodarczej i własności prywatnej”, a dopiero potem na „solidarności, dialogu i współpracy partnerów społecznych", co przesuwa na dalszy plan konieczność ochrony dobra wspólnego przez państwo ${ }^{43}$.

W 2015 r. rodzinom przedwojennych właścicieli lub kupcom roszczeń oddano w Warszawie ponad 300 budynków. W 2014 r. zagrożonych reprywatyzacją było w Warszawie około stu szkół i przedszkoli, kilkadziesiąt parków i terenów zielonych, kamienice z lokatorami, muzea i domy kultury, dziesiątki budynków administracji miejskiej i publicznej. Natomiast aktualna lista wszystkich nieruchomości objętych roszczeniami to wciąż ok. 2 tys. adresów ${ }^{44}$.

\section{Źródła lekceważenia i zaniedbywania sfery publicznej}

Naszkicowany powyżej obraz kryzysu i degradowania przestrzeni publicznych w Warszawie można uznać za zbyt ciemny i tendencyjny, ale odwołuje się on przecież do niewymyślonych faktów i ilustracji. Wskazane tendencje są naturalnie charakterystyczne nie tylko dla stolicy i dla innych miast w Polsce. Przywiązywanie mniejszej wagi do przestrzeni publicznej i zaniedbywanie jej widoczne jest także na terenach podmiejskich, na prowincji i w rejonach wiejskich. O preferowaniu domeny prywatnej, a nie publicznej, świadczy fakt, że troska Polaków o przestrzeń kończy się często na granicach własnej działki czy posesji. Prywatne domy i przydomowe ogródki coraz częściej błyszczą i kwitną, przypominając niekiedy miniaturowe Wersale, a wspólna droga dojazdowa nierzadko bywa już dziurawa i tonie w błocie. $Z$ jednej strony mamy te wszystkie wypielęgnowane trawniki, przystrzyżone finezyjnie krzaczki i tuje, wypieszczony grys na alejkach, a z drugiej - tuż obok za płotem często widać zanieczyszczone psimi odchodami chodniki.

Dotyczy to także prywatnych apartamentowców czy osiedli, gdzie tabliczki często ostrzegają, że zadbany trawnik to teren prywatny, strzeżony, zarezerwowany tylko dla grupy mieszkańców, zaś dalej, za ogrodzeniem jest przestrzeń wspólna, tereny

${ }^{43}$ Wywiad z W. Osiatyńskim, „Gazeta Wyborcza”, 28-29.11.2015.

${ }^{44}$ M. Zubik, Kolejne kamienice moga zostać zreprywatyzowane, „Gazeta Wyborcza” 23.02.2016. 
zielone dostępne dla ogółu. I tam m.in. mają załatwiać swoje potrzeby czworonogi należące do wszystkich mieszkańców. Regulamin niektórych zamkniętych osiedli wręcz zabrania wyprowadzania psów na wewnętrzny skwer.

Również w osiedlach podmiejskich i na obszarach wiejskich, podobnie jak w samych miastach, obserwujemy symptomy dezintegracji przestrzennej i społecznej. W obrębie lub w poblizzu dotychczasowych wsi wyrastają nowe wille twierdze lub zamknięte osiedla domów jednorodzinnych. Mieszkańcy napływowi na ogół nie integrują się z autochtonami, szczelnie odgradzają się od nich płotami, murami, systemami alarmowymi i ochroniarzami. Brakuje miejsc, gdzie te dwa światy mogłyby się spotkać. Nie jest to możliwe nawet w lokalnym sklepie czy szkole, gdyż nowa ludność napływowa robi zakupy w hipermarketach, zaś dzieci wozi na naukę do pobliskiego miasta.

Wielu cudzoziemców zaskakuje typowy dla Polski i Polaków kontrast w traktowaniu przestrzeni - z jednej strony prywatnej, a z drugiej publicznej. Ta pierwsza jest generalnie dużo bardziej doceniana i szanowana. To, co prywatne i zamknięte, jest w tej optyce dużo ważniejsze od tego, co publiczne i otwarte. Wystarczy tu przywołać, jako symboliczną ilustrację omawianej mentalności i wzoru zachowań, labiryntowy obraz parawanów, jakie wszechwładnie dominują w letnim sezonie na krajowych nadbałtyckich plażach.

Skąd bierze się to lekceważenie publicznej przestrzeni i dobra wspólnego przez rodaków? Jakie są tego przyczyny i uwarunkowania?

Z jednej strony, warto wskazać na historyczno-kulturową swoistość polskiej sytuacji pod tym względem. Po pierwsze, można w diagnozowanej tu niechęci do tego, co zbiorowe, dopatrywać się alergicznego odreagowywania realnego socjalizmu i PRL, gdzie niemal wszystko było kolektywne, państwowe, a więc publiczne, czyli w dość powszechnym odbiorze niczyje i marne. Neoficka, nadgorliwa wiara $\mathrm{w}$ indywidualizm, inicjatywę i własność prywatną, w wolny, niczym nieskrępowany rynek, w jego „żelazne prawa” i samoczynne mechanizmy wyznaczała po $1989 \mathrm{r}$. ruch świadomościowego wahadła w przeciwną stronę. Wyszarpywanie ze wspólnych zasobów społecznych jakichś „konfitur” dla siebie i swoich rodzin (amoralny familizm) stawało się dość powszechnym imperatywem i sposobem na życie.

Po drugie, w owym anty czy apublicznym nastawieniu i praktykach obecnego pokolenia Polaków widać symptomy powrotu do bardziej odległej przeszłości, w której prawa jednostki i własność prywatna w odniesieniu do uprzywilejowanej części narodu były świętością. Kwitła szlachecka wolność i liberum veto, a najważniejsze okazywały się własna zagroda i czubek własnego nosa. Szlachta zamykała się w swoich zaściankach i dworkach (niczym współcześni krezusi w rezydencjach i apartamentowcach), broniąc integralności własnego terytorium i swoich przywilejów, 
powtarzając wszem i wobec, że „szlachcic na zagrodzie równy wojewodzie” i „wolnoć, Tomku, w swoim domku".

Mentalność zagrodowa, warto zauważyć, ma także swoje chłopskie korzenie - bo czyż widział ktoś kiedyś tradycyjną wiejską chałupę bez płotu? Ogrodzenia niegdyś kleconego choćby z rachitycznych patyków czy wikliny, potem sztachet, drucianej siatki, a dziś, gdy dom rolnika jest już najczęściej porządnym murowańcem, płot jest także betonowy (popularne cementowe panele) bądź zbudowany z cegieł i solidnych, stalowych żerdzi. Potrzeba grodzenia na wsi wynikała między innymi z nieufności wobec obcego, a nawet sąsiada, który bywał traktowany jako potencjalne zagrożenie. Jak intruz, który - niczym stary Kargul w Samych swoich przed wojną - może wejść „w szkodę”, zaorać wspólną graniczną miedzę, choćby na szerokość dwóch czy trzech palców.

$\mathrm{Z}$ drugiej strony nie sposób jednak zaprzeczyć, że postponowanie domeny publicznej ma nie tylko specyficzne polskie historyczno-kulturowe uwarunkowania. Istotnie ważą tu także pewne współczesne, niekorzystne dla tej sfery, bardziej uniwersalne tendencje. Niezależnie od neoliberalnego trendu prywatyzacyjno-rynkowego, który przeorał światową gospodarkę i życie społeczne w ostatnich dwóch - trzech dekadach, nie bez znaczenia jest tu trwający już znacznie dłużej ogólniejszy kryzys wspólnoty i życia wspólnotowego na całym rozwiniętym Zachodzie. Panujący dookoła postmodernistyczny indywidualizm także w innych państwach zachodnich podminowuje i wygasza „ducha publicznego”. Pogłębiająca się kulturowa różnorodność i autonomia ludzkich wyborów, sposobów konsumpcji i stylów życia rozpuszcza w przestrzeni publicznej więzi społeczne, obniża poziom wzajemnego zaufania, nasila erozję publico bono.

\section{W stronę nowego urbanizmu?}

W dziedzinie kształtowania przestrzeni miejskich obserwujemy jednak ostatnio także symptomy procesów, które mogą zapowiadać odwrót od sygnalizowanych powyżej ogólniejszych, uniwersalnych tendencji. Ów kontrtrend to oznaki odbudowy i renesansu przestrzeni wspólnych na fali powracającej tęsknoty za potrzebami zbiorowymi, za tradycyjnymi wartościami i instytucjami, za mitologicznym „przyleganiem" do rzeczy oswojonych i dzielonych z innymi.

To moda na tzw. nowy urbanizm, który polega na uspołecznianiu i humanizacji przestrzeni miejskiej, na rekonstruowaniu w miastach starych bądź tworzeniu nowych przestrzeni publicznych - ogólnodostępnych i przyjaznych mieszkańcom i turystom, stanowiących tzw. miejsca trzecie, inne niż miejsca związane z zamieszkaniem i pracą. 
Tego rodzaju filozofia i zabiegi od jakiegoś czasu pozostają w centrum zainteresowania architektów, planistów, urbanistów i władz samorządowych zwłaszcza w krajach skandynawskich czy Holandii. W Szwecji idea otwarcia miasta na ludzi oraz ludzi na miasto, ułatwiająca budowanie więzi w społecznościach lokalnych, określana jest hasłem Oeppet foer livet.

Inspirowane podobnym myśleniem północnoeuropejskie wzory są coraz chętniej naśladowane w innych częściach Europy, także w niektórych miejscach w Polsce. Dobrymi przykładami mogą tu być zrewitalizowana Wyspa Młyńska na Brdzie w Bydgoszczy albo nowy Park Centralny w Olsztynie. Proces, który można by nazwać publicyzacją przestrzeni miejskiej, bywa też określany mianem „kopenhagizacji”, w nawiązaniu do osiągnięć stolicy Danii w tej dziedzinie. Gdyby zaś go rozumieć jeszcze szerzej, jako generalny wzrost znaczenia wartości i racji publicznych w polityce miejskiej czy ogólnopaństwowej na podstawie doświadczeń i inspiracji pochodzących z krajów skandynawskich, to można by mówić o swoistej „nordyzacji” życia społecznego i politycznego, albo - przestrzeni pojmowanej nie tylko w sposób fizyczny, ale i symboliczny.

Niektóre najnowsze inwestycje i wydarzenia w warszawskiej przestrzeni miejskiej dobrze wpisują się w zamiar jej humanizacji i oswajania, w doktrynę nowego urbanizmu. Przykładem prób odbudowywania wspólnej przestrzeni z inicjatywy i przy zaangażowaniu władz samorządowych mogą być działania zorientowane na otwarcie miasta na Wisłę, na lepsze i bardziej przyjazne ludziom zagospodarowanie obu brzegów rzeki. Powstały tam ostatnio ścieżki rowerowe, nowe miejsca przeznaczone na spacery, wypoczynek i rekreację, m.in. Park Fontann u podnóża Starego Miasta, w sezonie letnim zaczęły działać plaże, kluby i bary, trwa budowa eleganckich nabrzeżnych bulwarów (pierwszy ich fragment otwarto latem 2015 r.). Obok przedsięwzięć odgórnych mamy w tej dziedzinie do czynienia $\mathrm{z}$ wieloma oddolnymi inicjatywami społecznymi i rynkowymi, w tym osiedlowymi, jak np. skrzykujące się na forach internetowych grupy przekopujące klepiska i sadzące tam trawę i warzywa, ekologiczne biesiady na leżakach, zwane ekośniadaniami, weekendowe targi ze zdrową żywnością na Żoliborzu czy Jazdowie itp.

Za symptomatyczną akcję obywatelską można uznać próbę ożywienia, odzyskania i oddania ludziom we władanie przynajmniej części wyludnionej, betonowej przestrzeni w samym centrum miasta, jaką jest dziś Plac Defilad. Podjęto ją po raz pierwszy w 2014 r. na kawałku placu przed głównym wejściem do Pałacu oraz Teatru Studio, który zainicjował ten projekt. Najpierw postawiono tam ogromny długi stół, przy którym każdy mógł usiąść, zjeść coś, napić się, odpocząć. Rychło pojawiła się szeroka oferta koncertów, spotkań, debat, pokazów filmowych i innych wydarzeń kulturalnych. Przy okazji następnej edycji tego przedsięwzięcia w 2015 r., niezależnie 
od podobnego programu imprez, miejsce zamieniło się w mały ogród, bo też hasło przewodnie tego właśnie sezonu brzmiało „Miasto i ogród”. Główny motyw i cel projektu pozostał jednak ten sam: pobudzanie dyskusji o przyjaznej przestrzeni publicznej, o potrzebie bycia razem i sposobie budowania miejskiej wspólnoty lokalnej. W końcu maja 2016 r. zainaugurowano już trzecią edycję tego projektu. W ramach Ogrodu Miejskiego odbywać się będą różne akcje artystyczne, warsztaty rodzinne, dyskusje (m.in. Festiwal Kuronia, rekonstrukcja Okrągłego Stołu) itp., znów zamieniając na kilka letnich miesięcy „betonową codzienność” w kawałek poszukiwanej przez warszawiaków zielono-kulturalno-społecznej przestrzeni ${ }^{45}$.

Inną pozytywną, skromną próbą wykreowania deficytowej w Warszawie przestrzeni publicznej, tym razem podjętą przez sektor rynkowy, jest oddany do użytku w 2016 r. Plac Europejski na Woli, nieopodal stacji metra Rondo Daszyńskiego. Jest to w istocie pierwszy od czasów powojennej odbudowy, zaprojektowany i stworzony od zera, nowy miejski plac w stolicy. Przy czym, co wydaje się szczególnie oryginalne, został on sfinansowany nie ze środków publicznych i powstał nie na terenie miejskim, lecz na działce prywatnej, jako swego rodzaju „kaprys” prywatnego inwestora (belgijska firma Ghelamco Polska). Jest częścią kompleksu biurowego, ale stanowi ogólnodostępną przestrzeń o łącznej powierzchni 4 tys. m kw., do której wstęp mają wyłącznie piesi. Jako swoista oaza w betonowo-szklanym labiryncie tamtejszej zabudowy, przybrał hybrydalną formę placo-parku. Jest tu dużo roślinności, fontanna, kaskadowy strumień i nieduże jeziorko, placówki gastronomiczne, ale żadnych banków czy sklepów ${ }^{46}$. Krytyczni obserwatorzy już wskazują na ów brak szerszej oferty usług dla mieszkańców dzielnicy, na zbyt słabe powiązanie tej enklawy z przestrzenią wokół. Ale dopiero życie pokaże, czy to nowe miejsce to tylko rodzaj sztucznej scenografii i fajerwerk na pokaz, czy też raczej emanujący energetyczną witalnością plac publiczny.

Kolejną widowiskową próbą otwarcia i wtopienia nowych budynków w tkankę miasta, podjętą także przez sektor prywatny (firma Pro Urba), tyle że dotyczącą osiedla mieszkaniowego, jest 19. Dzielnica na Czystem, na Woli blisko ul. Towarowej. Ma być ona największym otwartym (bez płotów!) osiedlem w centrum miasta. Nowe uliczki, deptaki, place, skwery i inne tereny zielone będą powszechnie dostępną przestrzenią publiczną. Na parterach wszystkich budynków mają powstać sklepy, kawiarenki i punkty usługowe. Wideodomofony będą strzegły dostępu tylko do środka apartamentowców i na wewnętrzne prywatne dziedzińce.

${ }^{45}$ K. Bednarczykówna, Powrót Ogrodu, „Gazeta Wyborcza”, 27.05.2016.

${ }^{46}$ Więcej na temat tej inwestycji zob. P. Sarzyński, Przestrzenie w cenie, „Polityka” 2016, nr 7. 
Czy przytoczone wyżej przykłady ożywiania miejskich przestrzeni publicznych, współgrające z tendencją modną ostatnio w rozwiniętych krajach zachodnich, mogą zwiastować jakiś trwały odwrót od dominującego dotychczas w Warszawie trendu prywatyzacyjno-rynkowego? Czy miasto przestanie być postrzegane - nie tylko przez wielu jego mieszkańców - wyłącznie jako prosta suma prywatnych własności? Czy płot, ów swoisty symbol Polski nieufnej, wsobnej i prowincjonalnej, tak łatwo i wprost przenoszony ze środowiska wiejskiego w otoczenie miejskie, przestanie być nadużywanym (jeśli nie wręcz wszechobecnym i natrętnym) elementem pejzażu stolicy? Czas pokaże.

Nawiązując na koniec do zacytowanego na wstępie, jako motto artykułu, poglądu V. Havla, można by stwierdzić, że zainteresowanie tym, co jest za płotem - w odróżnieniu od troski o wyłącznie własny ogródek - wydaje się logicznym wstępem i warunkiem koniecznym zmian prowadzących do większego respektu dla dobra wspólnego, w tym także dla publicznych przestrzeni miejskich. Wzmocnienie takiego nastawienia na ogół nie przychodzi - i nie przyjdzie też w Warszawie - łatwo i szybko. Nie ma wszakże wątpliwości, że bez owego impulsu zainteresowania, bez otwartości oraz ciekawości świata i ludzi niemożliwe są również empatia, wyczucie i wrażliwość społeczna, odruchy solidarności, uznanie, że człowiek jest jednak zwierzęciem społecznym, a więc to wszystko, bez czego z kolei trudno sobie wyobrazić prowadzenie jakiejkolwiek rozumnej i skutecznej polityki publicznej.

\section{Bibliografia}

Atkinson R., Smith O., An Economy of False Securities? An Analysis of Murders inside Gated Residential Developments in the US, "Crime Media Culture" 2012, Vol. 8, No. 2.

Barber B., Gdyby burmistrzowie rzadzili światem, Warszawskie Wydawnictwo Literackie Muza SA, Warszawa 2014.

Bartoszewicz D., Biedronka Centralna klapa, „Gazeta Wyborcza”, 28.04.2015.

Bartoszewicz D., Pasaż Wiecha - reaktywacja, „Gazeta Wyborcza”, 27.11.2014.

Bartoszewicz D., Warszawa afrykańska, „Gazeta Wyborcza”, 17-18.11.2015.

Bauman Z., Razem osobno, Wydawnictwo Literackie, Kraków 2003.

Bednarczykówna K., Powrót Ogrodu, „Gazeta Wyborcza”, 27.05.2016.

Blakely E.J., Snyder G.M., Fortress America: Gated Communities in the United States, Brookings Institution Press, Washington 1999.

Castells M., Kwestia miejska, PWN, Warszawa 1982. 
Cesarski M., Fikcje rynku mieszkaniowego a prawo do miasta, w: Współczesny matrix? Fikcja w życiu gospodarczym, politycznym i społecznym, red. J. Osiński, Oficyna Wydawnicza SGH, Warszawa 2015.

Długowski Ł., Niech odżyją nasze miasta, „Gazeta Wyborcza”, 11-12.05.2013.

Domaradzki K., Przestrzeń Warszawy. Tożsamość miasta a urbanistyka, Muzeum Powstania Warszawskiego, Warszawa 2016.

Gądecki J., Za murami. Osiedla grodzone w Polsce - analiza dyskursu, Wydawnictwo Uniwersytetu Wrocławskiego, Wrocław 2009.

Gehl J., Życie między budynkami. Używanie przestrzeni publicznych, Wydawnictwo RAM, Kraków 2009.

Gettoizacja polskiej przestrzeni miejskiej, red. B. Jałowiecki, W. Łukowski, Wydawnictwo Naukowe Scholar, Warszawa 2007.

Habermas J., Strukturalne przeobrażenia sfery publicznej, Wydawnictwo Naukowe PWN, Warszawa 2007.

Harvey D., Bunt miast. Prawo do miasta i miejska rewolucja, Fundacja Bęc Zmiana, Warszawa 2012.

Jałowiecki B., Szczepański M.S., Miasto i przestrzeń w perspektywie socjologicznej, Wydawnictwo Naukowe Scholar, Warszawa 2002.

Karpieszuk W., Kiedyś było tu życie, teraz jak pustynia, „Gazeta Wyborcza”, 16.12.2013.

Lefebvre H., Prawo do miasta, „Praktyka Teoretyczna” 2012, nr 5.

Leszczyński A., Klasowy opór Żoliborza, „Gazeta Wyborcza”, 20-21.02.2016.

Lorens P., Definiowanie przestrzeni publicznej, w: Problemy kształtowania przestrzeni publicznej, red. P. Lorens, J. Martyniuk-Pęczek, Wydawnictwo Urbanista, Gdańsk 2012.

Merrifield A., Nowa kwestia miejska, Wydawnictwo Naukowe PWN, Warszawa 2016.

Nawratek K., Dziury w całym. Wstęp do miejskich rewolucji, Wydawnictwo Krytyki Politycznej, Warszawa 2012.

Osiński J., Sfera publiczna i sfera prywatna, w: Polityka publiczna we współczesnym świecie, red. J. Osiński, Oficyna Wydawnicza SGH, Warszawa 2014.

Piątek G., Miejskie pryszcze i nowotwory, „Gazeta Wyborcza”, 16.05.2014.

Pierre J., The Politics of Urban Governance, Palgrave Macmillan, Houndmills 2011.

Rydlewski G., Polska polityczna 2012/2013. Sfera publiczna jako środowisko decydowania politycznego, Dom Wydawniczy Elipsa, Warszawa 2014.

Sarzyński P., Przestrzenie w cenie, „Polityka” 2016, nr 7.

Springer F., Wanna z kolumnada. Reportaże o polskiej przestrzeni, Wydawnictwo Czarne, Wołowiec 2013.

Szpala I., M. Zubik, Dziwne przypadki reprywatyzacji, „Gazeta Wyborcza”, 29.04.2016.

Szpala I., M. Zubik, Jak przejąć ogródki na Szweda z Karaibów, „Gazeta Wyborcza”, 10.06.2016.

Theiss A., Jak się żyje w osiedlu zamkniętym, „Architektura Murator” 2008, nr 2.

Wojtczuk M., Świątynia za płotem, „Gazeta Wyborcza”, 21-22.05.2016. 
Wojtczuk M., Warszawa szybko rośnie, „Gazeta Wyborcza”, 5.05.2016.

Wojtczuk M., Wilanów odbija działki pod szkoły, „Gazeta Wyborcza”, 7-8.05.2016.

Wybieralski M., Duma i przerażenie, „Gazeta Wyborcza”, 16.05.2016.

Wybieralski M., Ratusz wycisza afere, „Gazeta Wyborcza”, 1.06.2016.

Wywiad z B. Barberem, „Gazeta Wyborcza”, 3.10.2014.

Wywiad z B. Jałowieckim, „Gazeta Wyborcza”, 15-16.11.2014.

Wywiad z J. Gądeckim i B. Jałowieckim, „Gazeta Wyborcza”, 15-16.11.2014.

Wywiad z J. Gehlem, „Gazeta Wyborcza”, 15.11.2013.

Wywiad z J. Rutkiewiczem, „Gazeta Wyborcza”, 11.03.2016.

Wywiad z M. Bajką, „Gazeta Wyborcza”, 4-5.10.2014.

Wywiad z V. Havlem, „Gazeta Wyborcza”, 21-22.11.1998.

Wywiad z W. Baraniewskim, „Gazeta Wyborcza”, 14.11.2014.

Wywiad z W. Karpińskim, „Gazeta Wyborcza”, 2-3.04. 2016.

Wywiad z W. Osiatyńskim, „Gazeta Wyborcza”, 28-29.11.2015.

Żoliborz przeciw mostowi, „Gazeta Wyborcza”, 22.02.2016.

Zubik M., Kolejne kamienice moga zostać zreprywatyzowane, „Gazeta Wyborcza”, 23.02.2016. 
